\section{O CONSUMO NA AMÉRICA LATINA E A FORMAÇÃO DE IDENTIDADES TRANSTERRITORIAIS}

\author{
CANCLINI, Néstor García. Consumidores e cidadãos: conflitos \\ multiculturais da globalização. Rio de Janeiro. Editora UFRJ, \\ 1995. 268p.
}

\section{Maurício Gomes de Faria}

Mestrando do Programa de Pós-Graduação em Ciências da Comunicação (PPGCOM), da Escola de Comunicações e Artes da USP (ECA-USP), com bolsa CAPES

E-mail: mauricio.gfaria@gmail.com

Publicada em 1995, a obra Consumidores e cidadãos: conflitos multiculturais da globalização, de Néstor Garcia Canclini, apresenta onze ensaios (divididos em quatro capítulos) que buscam problematizar o modo como o consumo altera as possibilidades e as formas de exercer a cidadania, bem como assume papel fundamental na construção identitária dos sujeitos. Nesse sentido, o hibridismo na relação consumidor/cidadão - afetada pela globalização e outros fenômenos sociais - é o grande objeto de investigação do autor em trabalhos realizados prioritariamente na Cidade do México e que se tornaram referência em toda a América Latina.

$\mathrm{Na}$ introdução, intitulada "Consumidores do século XXI, cidadãos do século XVIII", o autor levanta questionamentos sobre as transformações nos modos de participação coletiva, alegando que a descrença nas instituições públicas levou os indivíduos a buscarem respostas sobre suas próprias vivências e papéis sociais por meio do consumo privado de bens e dos meios de comunicação. Paralelamente, Canclini reforça que vivemos um constante processo de desintegração entre “o que é próprio e o que é alheio”, uma vez que os avanços tecnológicos de produção fizeram que as mercadorias perdessem fidelidade com seus locais originários, assim impulsionando a presença global das marcas. Enxergando no consumo um grande articulador cultural, o autor afirma que "a cultura é um processo de montagem multinacional, uma articulação flexível de partes, uma colagem de traços que qualquer cidadão de qualquer país, religião e ideologia pode ler e utilizar” (p. 17).

Em um segundo momento, o professor alerta que, para refletir sobre consumo e cidadania sob uma mesma perspectiva, é preciso desconstruir alguns julgamentos a respeito do comportamento dos consumidores. Para ele, o ato de consumir ainda está muito ligado à irracionalidade e ao supérfluo, ao mesmo tempo que a cidadania é reduzida a questões políticas.

Segundo Canclini, a partir do momento em que essas concepções forem repensadas e, enfim, a cidadania se aproximar do consumo e da comunicação de massa, será possível reconhecer os novos cenários de constituição do público e mostrar que para viver democraticamente "é indispensável admitir que o mercado de opiniões cidadãs inclui tanta variedade e dissonância quanto o mercado da moda, do entretenimento” (p. 34). 
Abrindo o capítulo "Cidades em globalização”, o autor define o termo "globalização” como passagem das identidades modernas (territoriais e monolinguísticas) para as identidades pós-modernas (transterritoriais e multilinguísticas). Posteriormente, no ensaio "O consumo serve para pensar", ressalta a inexistência de uma teoria sociocultural do consumo, e, por isso, torna-se de extrema importância que os esforços multidisciplinares - envolvendo comunicação, antropologia, sociologia e psicologia - caminhem rumo à conceituação dos processos de comunicação e recepção dos bens simbólicos.

A partir daí, somos apresentados a três linhas de trabalhos em que o consumo vem sendo problematizado ao longo da história. A primeira trata o consumo como lugar em que se completa o processo iniciado com a geração de produtos, expansão do capital e reprodução da força do trabalho. Na segunda, o consumo é visto como uma teoria mais complexa sobre a interação entre produtores e consumidores e entre emissores e receptores. Por fim, a terceira linha de pesquisa lida com o consumo enquanto lugar de diferenciação e distinção entre classes e grupos, contemplando aspectos simbólicos e estéticos da racionalidade consumidora. Para Canclini, "só através da reconquista criativa dos espaços públicos, do interesse pelo público, o consumo poderá ser um lugar de valor cognitivo, útil para pensar e agir significativa e renovadoramente na vida social” (p. 68).

No ensaio seguinte, "México: a globalização cultural numa cidade que se desintegra", o autor deseja mostrar a vinculação entre a crise das megacidades e a crise do conhecimento social por meio de seus estudos realizados na Cidade do México (e parte em Buenos Aires e São Paulo). Para ele, a polifonia caótica das metrópoles influencia diretamente na construção discursiva e identitária do indivíduo, resultando em um processo de dissolução das monoidentidades. Essa constatação está no centro do embate entre a cultura transnacional desterritorializada e a resistência da intervenção estrangeira nas estruturas sociais locais. Neste momento, Canclini se apropria do termo "glocalização" para explicar as adaptações dos produtos globais às diferentes culturas locais a fim de compartilhar códigos comuns ao repertório dos sujeitos.

No terceiro capítulo, "Subúrbios pós-nacionais", continua sua reflexão sobre a transnacionalização comercial e cultural projetada na construção de identidade, mas exemplifica suas afirmações por meio da submissão de países latino-americanos aos Estados Unidos. Nesse momento, Canclini traça um panorama histórico da indústria midiática americana - sobretudo do mercado cinematográfico - e reforça que essa hegemonia está totalmente atrelada à facilidade/agilidade de adaptação frente às mudanças tecnológicas e aos hábitos culturais. Além disso, relaciona a decadência audiovisual dos países latinos com o baixo grau de controle das redes de comunicação, desde a captação até a disseminação de conteúdo, e o despreparo para enxergar filmes enquanto produtos multimídias.

Por fim, no último capítulo, "Negociação, integração e desconexão", Canclini disserta sobre um cenário de tríplice crise: na identidade, nas classes sociais e no popular. Para ele, os conflitos acontecem em diferentes níveis, e o contato do indivíduo com os produtos culturais populares torna-se negociável, superficial e passageiro. Como solução, vislumbra um "multiculturalismo democrático" a partir da compreensão e da modulação da cultura contemporânea junto a sua tensão entre a modernização acelerada e as críticas à modernidade. 
Ainda neste capítulo, o autor reforça a deficiência do Estado para lidar com os gradientes do consumo, da cultura e da cidadania que permeiam as relações humanas, afirmando que "as críticas às ações dos governos e as análises das mudanças socioculturais contidas neste livro buscam pensar a incapacidade das políticas para absorver o que está acontecendo na sociedade civil” (p. 247)

Em suma, o livro é um dos grandes referenciais teóricos para quem deseja trabalhar o consumo em paralelo ao exercício da cidadania sob uma perspectiva latino-americana. A proximidade com a realidade brasileira marcou um importante avanço no campo, trazendo grandes benefícios para o desenvolvimento dos estudos da comunicação e consumo, uma vez que pesquisadores se apoiavam principalmente em autores europeus cujo distanciamento dificultava a análise do objeto.

Apesar de ser um livro antigo, levando-se em consideração as inúmeras transformações sociais e tecnológicas na comunicação, é possível afirmar que os apontamentos de Canclini ainda são extremamente relevantes e conseguem dialogar facilmente com temáticas atuais. Cada vez mais, como o próprio autor coloca, os estudos de consumo não devem se concentrar nas diferenças, mas, sim, no caráter agregador, híbrido, que baliza as relações entre os indivíduos. 